\title{
PENGARUH PERTUMBUHAN PERUSAHAAN, LIKUIDITAS, RESIKO BISNIS DAN STRUKTUR ASSET TERHADAP STRUKTUR MODAL DENGAN PROFITABILITAS SEBAGAI VARIABEL MODERASI
}

\author{
${ }^{1}$ Agustin Nur'aini \\ ${ }^{2}$ Dra.Endang Masitoh W \\ ${ }^{3}$ Yuli Chomsatu \\ ${ }^{1,2,3}$ Program Studi Akuntansi, Universitas Islam Batik Surakarta \\ email:agustinnuraini08@gmail.com
}

\begin{abstract}
Abstrak
Struktur modal adalah salah satu keputusan keuangan yang kompleks karena terkait dengan variabel keputusan keuangan lainnya.Tujuan dari penelitian ini adalah untuk menganalisis faktor-faktor yang mempengaruhi struktur modal dengan profitabilitas sebagai variabel moderasi.Populasi dalam penelitian ini adalah perusahaan subsektor makanan dan minuman yang terdaftar.di Bursa Efek Indonesia di 2014-2018. Teknik pengambilan sampel dalam penelitian ini menggunakan metode purposive sampling dan diperoleh sampel sebanyak 12 perusahaan. Metode analisis data menggunakan uji asumsi klasik dan analisis regresi linier berganda menggunakan SPSS 20. Hasil analisis data menunjukkan pertumbuhan perusahaan dan risiko bisnis tidak berpengaruh terhadap struktur modal, sedangkan likuiditas memiliki pengaruh negatif dan signifikan terhadap struktur modal, aset struktur berpengaruh positif dan signifikan terhadap struktur modal sedangkan profitabilitas berpengaruh negatif terhadap struktur modal. Profitabilitas tidak dapat memoderasi pengaruh pertumbuhan perusahaan, risiko bisnis dan struktur aset pada struktur modal tetapi profitabilitas mampu memoderasi pengaruh likuiditas terhadap struktur modal.
\end{abstract}

Kata Kunci: DER, ROA, Structure asset, CR, Growth, Risk Bussiness

\begin{abstract}
Capital structure is one of the complex financial decisions because it is related to other financial decision variables. The purpose of this study is to analyze the factors that influence the capital structure with profitability as a moderating variable. The population in this study is the registered food and beverage sub-sector companies. on the Indonesia Stock Exchange in 2014-2018. The sampling technique in this study used a purposive sampling method and obtained a sample of 12 companies. The data analysis method uses the classical assumption test and multiple linear regression analysis using SPSS 20, with the results of data analysis showing company growth and business risk has no effect on capital structure, while liquidity has a negative and significant effect on capital structure, asset structure has a positive and significant effect on structure capital while profitability has a negative effect on capital structure. Profitability is not able to moderate the effect of company growth, business risk and asset structure on capital structure but profitability is able to moderate the effect of liquidity on capital structure.
\end{abstract}

Keywords: DER, ROA, Structure asset, CR, Growth, Risk Bussiness

\section{PENDAHULUAN}

Perusahaan sebagai suatu badan usaha yang melakukan kegiatan ekonomi tentunya memiliki tujuan. Tujuan perusahaan bisa tercapai apabila adanya keberhasilan tugas seorang manajer keuangan yaitu berhati-hati dalam melakukan manajemen keuangan, karena setiap keputusan yang diambil akan berpengaruh terhadap keputusan keuangan yang lainnya yang akan berdampak pada keuangan perusahaan dan berpengaruh terhadap keberlangsungan hidup suatu perusahaan. Sedangkan struktur modal sendiri Menurut (Sartono, 2001) 
merupakan kombinasi utang dan ekuitas dalam struktur keuangan jangka panjang perusahaan. proporsi penggunaan antara hutang dan ekuitas. Manajemen sebagai pengelola tentu harus menyeimbangkan penggunaan hutang dan ekuitas untuk mencapai struktur modal yang optimal.Structure asset, growth opportunity, profitabilitas, resiko bisnis termasuk faktor yang berpengaruh terhadap struktur modal. Dalam penelitian ini akan menggunakan Pertumbuhan perusahaan, Likuiditas, Resiko Bisnis, Struktur Asset dan Profitabilitas sebagai variabel moderasinya.

Menurut (Sartono, 2001) profitabilitas adalah kemampuan perusahaan memperoleh laba yang berhubungan dengan penjualan, total aktiva, maupun modal sendiri. (Brigham dan Housten, 2011) menyatakan bahwa perusahaan dengan tingkat keuntungan yang tinggi, umumnya menggunakan relatif sedikit karena dengan keuntungan yang tinggi tersebut dapat digunakan perusahaan melakukan permodalan hanya dengan laba ditahan saja.

(Kusmuriyanto, 2005) Aset adalah semua kekayaan yang dimiliki perusahaan dan memberikan manfaat ekonomis dimasa yang akan datang). Sesuai dengan theory signaling, pentingnya memberikan informasi terkait kondisi laporan keuangan terhadap pihak eksternal terutama kepada pihak investor supaya tidak terjadi informasi asimetri yang mengakibatkan menurunnya nilai suatu perusahaan,

Likuiditas adalah rasio yang digunakan untuk mengukur kemampuan perusahaan didalam membayar kewajiban jangka pendek (Horne, et al., 2007). Rasio ini merupakan alat ukur suatu perusahaan untuk menilai kemampuan dalam melunasi kewajiban-kewajiban jangka pendek atau kewajiban lancar saat jatuh tempo. Dalam penelitian ini likuiditas diukur dengan Current Ratio (CR). Current Ratio yaitu perbandingan antara aktiva lancar dengan kewajiban lancar (Brealey, et al., 2008).

Brigham dan Housten (2011 : 157) resiko bisnis merupakan resiko asset perusahaan jika perusahaan tidak menggunakan hutang, resiko bisnis dapat meningkat ketika perusahaan menggunakan hutang yang tinggi untuk memenuhi kebutuhan pendanaannya. Resiko timbul seiring dengan munculnya beban biaya atas pinjaman yang dilakukan perusahaan.

Struktur asset adalah perbandingan antara aktiva tetap dengan total aktiva yang dimiliki perusahaan (Tijow, et al,. 2018). Perusahaan yang memiliki nilai asset tetap yang lebih besar, memiliki jaminan pinjaman yang memadai sehingga cenderung memiliki hutang yang besar, artinya semakin besar struktur asset, maka struktur modal perusahaan yang berasal dari utang akan semakin meningkat. Apabila perusahaan mengalami kepailitan dalam memenuhi kewajibannya untuk mebayar pinjaman, maka asset tetap yang dimiliki dapat di jadikan jaminan atau dijual untuk dikonfersi menjadi kas (Batu bara et al,. 2017) Dewiningrat dan Ketut (2018).

Penelitian ini bertujuan (1) Untuk mengetahui pengaruh pertumbuhan perusahaan, likuiditas, resiko bisnis, struktur asset dan profitabilitas terhadap struktur modal. (2) Untuk mengetahui apakah Profitabilitas mampu memoderasi pertumbuhan perusahaan, likuiditas, resiko bisnis dan pertumbuhan perusahaan terhadap struktur modal.

\section{TINJAUAN LITERATUR}

\section{Teori Signalling}

Brigham dan Housten (2014) isyarat atau signal adalah suatu tindakan yang diambil perusahaan untuk memberi petunjuk bagi investor tentang bagaimana manajemen memandang prospek perusahaan. Sinyal ini berupa informasi mengenai apa yang sudah dilakukan oleh manajemen untuk merealisasikan keinginan pemilik. Informasi yang dikeluarkan oleh perusahaan merupakanhal yang penting, karena pengaruhnya terhadap keputusan investasi pihak diluar perusahaan.

\section{Struktur Modal}

Struktur Modal adalah perimbangan antara penggunaan modal pinjaman dengan modal sendiri. Struktur modaldapat diukur dengan Debt to Equity Ratio (DER), DER merupakan salah satu rasio dari leverage yang bertujuan untuk mengukur kemampuan dari modal sendiri 
yang dijadikan jaminan untuk keseluruhan hutang perusahaan. Menurut Brigham \& Houston (2011) struktur modal diproksikan dengan Debt to Equity Ratio (DER)yang dapat dihitung dengan rumus :

$$
\text { DER }=\frac{\text { Total Hutang }}{\text { Total Ekuitas }}
$$

\section{Profitabilitas}

Gitman (2003), profitabilitas adalah hubungan antara pendapatan dan biaya yang dihasilkan dengan menggunakan asset perusahaan, baik lancar maupun tetap, dalam aktivitas produksi. Menurut (Brealey dan Myers, 2008:81 )Profitabilitas dapat diukur dengan return on asset $(\mathrm{ROA})$ :

$$
\text { ROA }=\frac{\text { Laba Bersih }}{\text { Total Asset }}
$$

\section{Pertumbuhan Perusahaan}

Pertumbuhan Perusahaan adalah semua kekayaan yang dimiliki perusahaan dan memberikan manfaat ekonomis dimasa yang akan datang (Kusmuriyanto, 2005). Pertumbuhan perusahaan Menurut (Titman dan Wassels, 1988) pertumbuhan perusahaan dapat diukur dengan rumus sebagai berikut :

$$
\text { Pertumbuhan Perusahaan }=\frac{\text { Total asset } t-\text { Total asset } t-1}{\text { Total asset } t-1}
$$

\section{Likuiditas}

Likuiditas adalah kemampuan perusahaan untuk membayar kewajiban finansial jangka pendek tepat pada waktunya. Likuiditas perusahaan ditunjukkan oleh besar kecilnya aktiva lancar yaitu aktiva yang mudah diubah untuk menjadi kas yang meliputi kas, surat berharga, piutang, persediaan. Rasio likuiditas diukur menggunakan current ratio. Current ratio (CR) merupakan sebuah rasio likuiditas yang menggambarkan sampai sejauh apa kewajiban lancar ditutupi oleh aset lancer. Menurut (Brigham, \& Housten, 2011) Likuiditas dapat diukur dengan rumus sebagai berikut :

$$
C R=\frac{\text { Aktiva Lancar }}{\text { Hutang Lancar }}
$$

\section{Risiko Bisnis}

Resiko Bisnis adalah resiko bisnis merupakan resiko asset perusahaan jika perusahaan tidak menggunakan hutang, resiko bisnis dapat meningkat ketika perusahaan menggunakan hutang yang tinggi untuk memenuhi kebutuhan pendanaannya Brigham dan Housten (2011 : 157) . Menurut (Amalia \& Hidayati, 2016) resiko Bisnis dapat diukur menggunakan:

$$
\text { Resiko Bisnis }=\frac{\text { EBIT }}{\text { Total Asset }}
$$

\section{Struktur Aktiva}

Struktur Asset merupakan variabel yang penting dalam keputusan pendanaan perusahaan dengan karena aktiva tetap berhubungan dengan proses produksi perusahaan untuk mendapatkan ataupun meningkatkan laba perusahaan. Struktur aktiva adalah perbandingan antara aktiva tetap dengan total aktiva. Perhitungan struktur aktiva adalah sebagai berikut (Denziana \& Yunggo, 2017)

$$
\text { Struktur Aktiva }=\frac{\text { Aktiva Tetap }}{\text { Total Aktiva }} \times 100 \%
$$




\section{Kerangka Berfikir}

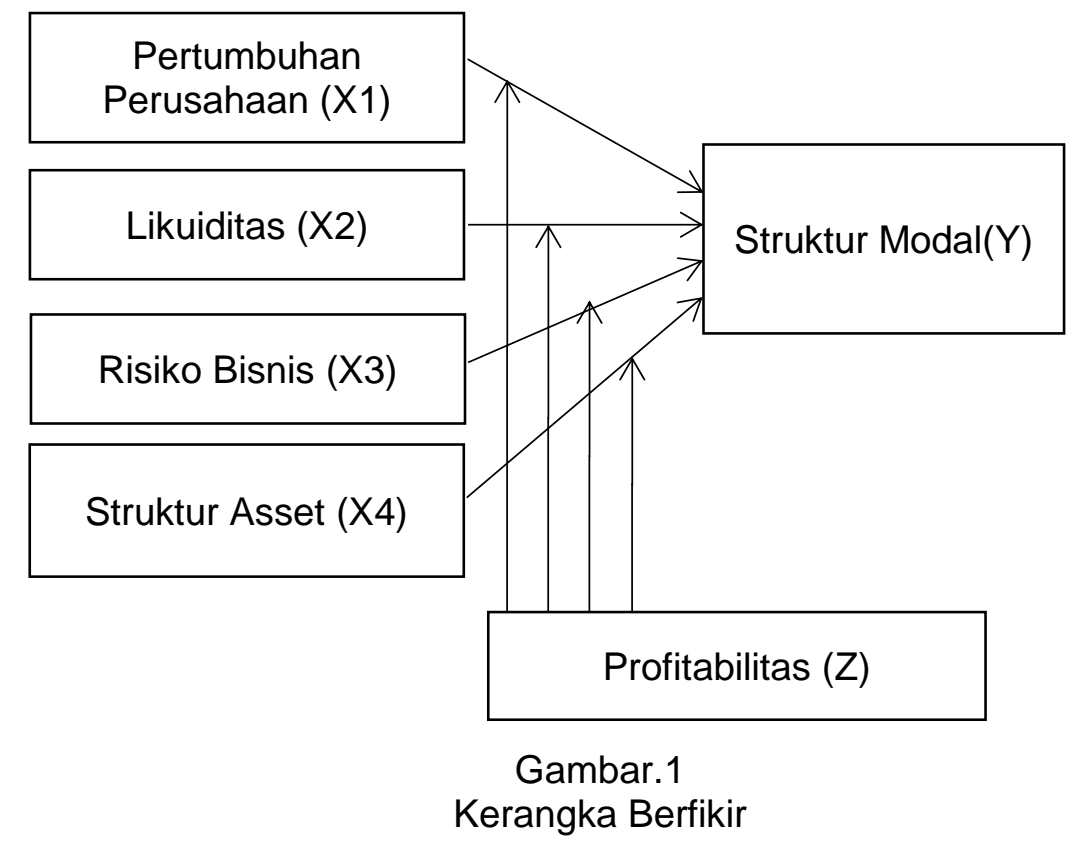

\section{PENGEMBANGAN HIPOTESIS}

\section{Pengaruh Pertumbuhan Perusahaan terhadap Struktur Modal}

Saidi (2004) Perusahaan dengan tingkat pertumbuhan yang tinggi, akan terjadi kekurangan pendapatan untuk mendanai pertumbuhan tinggi tersebut secara internal. Dalam penelitiannya Hanna Hidayah Wijayanti (2017) menyatakan bahwa pertumbuhan perusahaan berpengaruh terhadap struktur modal.Jadi dapat diajukan hipotesis sebagai berikut : $\mathrm{H}_{1}$ :Pertumbuhan perusahaan berpengaruh terhadap Struktur modal

\section{Pengaruh Likuiditas terhadap Struktur Modal}

Perusahaan dengan tingkat likuiditas yang tinggi, berarti perusahaan memiliki kelebihan aset lancer yang cukup untuk membiayai operasional perusahaan tanpa harus meminjam dana dari pihak luar. Dian Masita Dewi (2016) meneliti mengenai struktur modal dan menyatakan bahwa Likuiditas berpengaruh terhadap struktur modal. Jadi dapat diajukan hipotesis sebagai berikut

$\mathrm{H}_{2}$ : Likuiditas berpengaruh terhadap Struktur modal.

\section{Pengaruh Resiko Bisnis terhadap Struktur Modal}

Chan dan Saidi (2004) menyatakan bahwa perusahaan yang memiliki tingkat risiko yang tinggi cenderung menghindari penambahan pendanaan melalui modal asing dibandingkan dengan perusahaan yang memiliki tingkat risiko yang rendah.KT. Lanang Syahputra (2014) meneliti mengenai struktur modal dan menyatakan bahwa resiko bisnis berpengaruh terhadap struktur modal. Jadi dapat diajukan hipotesis sebagai berikut $\mathrm{H}_{3}$ : Resiko Bisnis berpengaruh terhadap Struktur modal.

\section{Pengaruh Stuktur Asset terhadap Struktur Modal}

Weston dan Copeland (2013) menyatakan bahwa perusahaan yang mempunyai asset tetap jangka panjang lebih besar, maka perusahaan tersebut akan banyak menggunakan utang jangka panjang, I Wayan Martha Mandana dan Luh Gede Sri Artini (2015) \&Muhammad Tasir,et al (2016) meneliti mengenai struktur modal dan menyatakan bahwa Struktur Asset berpengauh terhadap struktur modal. Jadi dapat diajukan hipotesis sebagai berikut $\mathrm{H}_{4}$ :Struktur asset berpengaruh terhadap Struktur modal. 


\section{Pengaruh Profitabilitas terhadap Struktur Modal}

Profitabilitas dalam kaitannya dengan struktur modal mempunyai pengaruh dimana perusahaan yang mempunyai profitabiitas tinggi akan mengurangi ketergantungannya degan pihak luar karena tingkat keuntungan yang tinggi memungkinkan perusahaan untuk memperoleh sebagian besar pendanaannya dari laba ditahan. Hal ini sesuai dengan penelitian Riski Ayu Pratiwi Batubara, et al (2017), Sehingga dapat diajukan hipotesis sebagai berikut :

$\mathrm{H}_{5}$ :Profitabilitas Berpengaruh terhadap Struktur Modal

Pengaruh Pertumbuhan perusahaan terhadap Struktur Modal yang di moderasi oleh Profitabilitas.

Ketikapertumbuhan penjualan suatu perusahaan baik maka akan meningkat pula pertumbuhan sebuah perusahaan, dengan meingkatnya pertumbuhan sebuah perusahaan pasti akan menambah laba bagi perusahaan yang berarti perusahaan memiliki profitabilitas yang tinggi, apabila peruusahaan memiliki profitabilitas tinggi maka semakin kecil tingkat penggunaan hutangnya, karena tersedianya laba ditahan, sehingga dapat menekan tingkat hutang, hal ini sejalan dengan penelitian yang dilakukan oleh Diana Dwi Astuti dan Chusnul Hotima (2016). Dengan demikian dapat diajukan hipotesis sebagai berikut :

$\mathrm{H}_{6}$ :Profitabilitas mampu memoderasi pengaruh pertumbuhan perusahaan terhadap struktur modal.

\section{Pengaruh Likuiditas terhadap Struktur Modal yang di moderasi oleh Profitabilitas}

Adanya profitabilitas sebagai variabel moderasi sangat mempengaruhi besarnya dividen tunai yang dibayarkan. Aktiva lancar yang tersedia terlalu tinggi yang digunakan untuk melunasi kewajiban keuangan yang akan jatuh tempo, sehingga ada aktiva produktif yang tidak dimanfaatkan oleh perusahaan untuk meningkatkan profitabilitas (Ambarwati dkk, 2015). Jika likuiditas tinggi maka investor berpeluang mendapatkan dividen tunai yang cukup tinggi. Hal ini sejalan dengan penelitian yang dilakukan oleh Muchammad Chaerul Umam (2016)Dengan demikian dapat diajukan hipotesis sebagai berikut :

$\mathrm{H}_{7}$ :Profitabilitas mampu memoderasi pengaruh likuiditas terhadap struktur modal.

\section{Pengaruh Resiko Bisnis terhadap Struktur Modal yang di moderasi oleh Profitabilitas}

Nuswandari (2013) mengatakan bahwa perusahaan yang mempunyai profitabilitas tinggi akan mengalokasikan sebagian besar keuntungannya pada laba yang tidak dibagi, sehhingga perusahaan akan menggunakan dana internal yang dimilikinya untuk memenuhi kebutuhan pendanaan perusahaan. Perusahaan yang memiliki laba bersih tinggi akan cenderung mengurangi penggunaan hutang pada pihak luar, hal ini berarti dengan adanya profitabilitas sebagai variabel moderasi antara pengaruh resiko bisnis terhadap struktur modal dapat mempengaruhi pengaruh resiko bisnis terhadap struktur modal. Hal ini sejalan dengan penelitian Danik Karyawati, Y Djoko Suseno dan Rispantyo (2017). Dengan demikian dapat diajukan hipotesis sebagai berikut :

$\mathrm{H}_{8}$ :Profitabilitas mampu memoderasi pengaruh resiko bisnis terhadap struktur modal.

\section{Pengaruh Struktur Asset terhadap Struktur Modal yang di moderasi oleh Profitabilitas}

Besar kecilnya struktur aktiva akan menentukan struktur modal perusahaan. Brigham dan Housten (2001 : 184) menyatakan bahwa secara umum perusahaan yang memiliki jaminan terhadap hutang akan lebih mudah mendapatkan hutang daripada perusahaan yang tidak memiliki jaminan. Apabila struktur asset perrusahaan itu tinggi berarti jumlah aktiva tetap mereka juga besar. Perusahaan yang memiliki aktiva tetap dalam jumlah besar dapat menggunakan hutang dalam jumlah besar, dikarenakan besarnya aktiva tetap tersebut dapat dijadikan sebagai jaminan utangnya. Profitabilitas dapat memoderasi pengaruh struktur aktiva terhadap struktur modal. Tingkat profitabilitas dapat dijadikan acuan oleh pihak kreditur dalam memberikan pinjaman, perusahaan dengan profitabilitas yang tinggi, berarti laba bersih yang dimiliki perusahaan juga tinggi, maka hal tersebut dapat memberikan sinyal kepada pihak kreditur, sehingga perusahaan dapat dengan mudah mendapat pinjaman dana dari 
pihak luar. Hal ini sejalan dengan penelitian yang dilakukan oleh Bingah Susantika (2019). Dengan demikian dapat diajukan hipotesis sebagai berikut :

$\mathrm{H}_{9}$ :Profitabilitas mampu memoderasi pengaruh Struktur Asset terhadap struktur modal.

\section{METODOLOGI PENELITIAN}

Penelitian ini menggunakan metode kuantitatif karena data yang digunakan berupa angka-angka yang bersumber dari laporan keuangan. Menurut Sugiyono (2003) penelitian kuantitatif adalah penelitian dengan memperoleh data yang berbentuk angka atau data kualitatif yang diangkakan.

Populasi yang digunakan dalam penelitian ini adalah perusahaan makanan dan minuman yang terdaftar di Bursa EfekIndonesia (BEI) tahun 2014-2018 sebanyak 26 perusahaan. Kriteria sampel ditentukan dengan metode purposive sampling (1) perusahaan makanan dan minuman yang melaporkan laporan keuangan secara lengkap pada tahun 2014-2018, (2) perusahaan makanan dan minuman yang mempunyai data lengkap terkait dengan variabel yang digunakan, (3) perusahaan makanan dan minuman yang tidak mengalami kerugian pada tahun 2014-2018 (4)perusahaan yang melaporkan laporan keuangannya dalam bentuk rupiah. Dari kriteria tersebut didapat sampel sebanyak 12 perusahaan.

Sumber data yang digunakan dalam penelitian ini adalah data sekunderlaporan keuangan perusahaan makanan dan minuman yang terdaftar di Bursa Efek Indonesia (BEI) tahun 2014-2018. Pengujian hipotesis menggunakan analisis regresi linear berganda

\section{HASIL DAN PEMBAHASAN}

Uji REgresi Linier Berganda

Tabel 6

Model Regresi 1

\begin{tabular}{cc}
\hline Variabel & B \\
Constant & 0,804 \\
Pertumbuhan & $-0,214$ \\
perusahaan & $-12,675$ \\
Likuiditas & 0,147 \\
Resiko Bisnis & 1,180 \\
Struktur Asset & $-1,977$ \\
Profitabilitas &
\end{tabular}

erdasarkan hasil pengujian diatas dengan menggunakan program SPSS 20, maka didapat persamaan regresi untuk model 1 sebagai berikut :

$$
Y_{1}=0,804-0,214 X_{1}-12,675 X_{2}+0,147 X_{3}+1,180 X_{4}-1,977 X_{5}+e
$$

Tabel 7

Model Regresi 2

\begin{tabular}{cc}
\hline Variabel & B \\
Constant & 1,079 \\
Pertumbuhan & \\
perusahaan*Profitabilitas & $-3,717$ \\
Likuiditas*Profitabilitas & $-124,701$ \\
Resiko & $-5,689$ \\
Bisnis*Profitabilitas & 1,396 \\
Struktur & \\
Asset*Profitabilitas & Sampiran(Olah data Spss 20
\end{tabular}


Berdasarkan hasil pengujian diatas dengan menggunakan program SPSS 20 , maka didapat persamaan regresi untuk model 2 sebagai berikut :

\begin{tabular}{|c|c|c|c|c|c|}
\hline & & $\begin{array}{r}\text { Tabel } \\
\text { Kelayaka }\end{array}$ & Model & & \\
\hline Hipotesis & Fhitung & $\mathrm{F}$ table & Sig & Syarat & Keputusan \\
\hline $\mathrm{Ha}$ & 5,812 & 2,543 & 0,000 & $<0,05$ & Simultan \\
\hline
\end{tabular}

Berdasarkan pada tabel 4.8, diperoleh $\mathrm{F}$ hitung sebesar 5,812> F tabel sebesar 2,543 dan signifikansi sebesar $0,000<0,05$ sehingga terlihat bahwa nilai signifikansi tersebet lebih kecil dari 0,05 . Hal ini menunjukan bahwa variabel independen signifikansi secara bersamasama berpengaruh terhadap variabel dependen.

Tabel 9.

Uji Hipotesis

\begin{tabular}{cccccc}
\hline Hipotesis & T Hitung & T tabel & Sig & Syarat & Kesimpulan \\
\hline $\mathrm{H}_{1}$ & $-0,600$ & 2,005 & 0,551 & $<0,05$ & Ditolak \\
$\mathrm{H}_{2}$ & $-3,292$ & 2,005 & 0,002 & $<0,05$ & Diterima \\
$\mathrm{H}_{3}$ & 0,337 & 2,005 & 0,737 & $<0,05$ & Ditolak \\
$\mathrm{H}_{4}$ & 3,809 & 2,005 & 0,000 & $<0,05$ & Diterima \\
$\mathrm{H}_{5}$ & $-4,272$ & 2,005 & 0,000 & $<0,05$ & Diterima \\
$\mathrm{H}_{6}$ & $-0,877$ & 2,005 & 0,384 & $<0,05$ & Ditolak \\
$\mathrm{H}_{7}$ & $-3,758$ & 2,005 & 0,000 & $<0,05$ & Diterima \\
$\mathrm{H}_{8}$ & $-1,916$ & 2,005 & 0,061 & $<0,05$ & Ditolak \\
$\mathrm{H}_{9}$ & 1,186 & 2,005 & 0,241 & $<0,05$ & Ditolak \\
\hline
\end{tabular}

Sumber : Lampiran(Olah data Spss 20)

Berdasarkan tabel diatas maka uji hipotesis memperolh hasil sebgai berikut :

a. Pertumbuhan Perusahaan tidak berpengaruh terhadap struktur modal

b. Likuiditas berpengaruh terhadap struktur modal

c. Resiko bisnis tidak berpengaruh terhadap struktur modal

d. Struktur Asset berpengaruh terhadap struktur modal

e. Profitabilitas berpengaruh terhadap struktur modal

f. Profitabilitas tidak dapat memoderasi pengaruh pertumbuhan perusahaan terhadap struktur modal

g. Profitabilitas dapat memoderasi pengaruh likuiditas terhadap struktur modal

h. Profitabilitas tidak dapat memoderasi pengaruh resiko bisnis terhadap struktur modal

i. Profitabilitas tidak dapat memoderasi pengaruh struktur asset terhadap struktur modal

Tabel 10

Uji Koefisien Determinasi

$\begin{array}{cc}\text { Adjusted R Square } & \text { Kesimpulan } \\ \text { Sumber : Lampiran(Olah data Spss } 20)\end{array}$

Diperoleh nilai adjusted $R^{2} 51,1 \%$ sehingga dapat disimpullkan bahwa variabel pertumbuhan perusahaan (X1), Likuiditas (X2), Resiko Bisnis (X3), Struktur Asset (X3) mempengaruhi struktur modal $(Y)$ sebesar $51,1 \%$ dan $48,9 \%$ dipengaruhi oleh faktor lain yang tidak diteliti dalam penelitian ini. Dengan demikian maka dapat disimpulkan bahwa 
keberadaan variabel profitabilitas dapat memperlemah atau menurunkan pengaruh variabel Independen terhadap variabel dependen.

Pengaruh pertumbuhan perusahaan terhadap struktur modal dalam penelitian ini menunjukkan bahwa nilai t hitung $-0,600$ dengan tingkat signifikan 0,551 . Hal ini berarti bahwa pertumbuhan perusahaan tidak berpengaruh terhadap struktur modal.Maka semakin besarnya pertumbuhan perusahaan maka semakin rendah struktur modal, besarnya pertumbuhan perusahaan terjadi karena kemampuan suatu perusahaan dalam melakukan penjualan sesuai yang diharapkan oleh suatu perusahaan. Penelitian ini sejalan dengan penelitian Diana Dwi Astuti dan Chusnul Hotima (2016).

Pengaruh likuiditas terhadap struktur modal, dalam penelitian ini menunjukkan nilai $t$ hitung $-3,292$ dengan tingkat signifikan 0,002 . Hal ini berarti likuiditas berpengaruh negatif dan signifikan terhadap struktur modal, Ini berarti bahwa setiap adanya peningkatan likuiditas akan ceenderung menurunkan nilai struktur modal ini berarti bahwa perusahaan yang memiliki tingkat likuiditas yang lebih tinggi, akan menggunakan dana internal lebih dulu dan akan menurunkan tingkat pembiayaan eksternalnya. Hasil penelitian ini sejalan dengan hasil penelitian yang dilakukan oleh Mahvish Sabir dan Qaisar Ali Malik (2013)

Pengaruh resiko bisnis terhadap struktur modal, dalam penelitian ini menunjukkan bahwa nilai t hitung 0,337 dan nilai signifikan 0,737 . Hal ini berarti resiko bisnis tidak berpengaruh terhadap struktur modal.Perusahaan yang memiliki tingkat resiko bisnis yang tinggi cenderung menghindari penambahan modal dari pihak eksternal dibandingkan dengan perusahaan yang memiliki tingkat resiko bisnis lebih rendah, dikarenakan untuk menghindari terjadinya peluang kebangkrutan. Penelitian ini sejalan dengan hasil penelitian Diana Dwi Astuti dan Chusnul Hotima (2016).

Pengaruh struktur asset terhadap struktur modal, dalam penelitian ini menunjukkan bahwa nilai t hitung 3,809 dan nilai signifikan 0,000. Hal ini berarti resiko bisnis berpengaruh positif dan signifikan terhadap struktur modal. Hal ini menunjukkan semakin tinggi struktur asset perusahaan, maka tingkat hutang perusahaan akan cenderung meningkat dampaknya nilai struktur modal akan meningkat. Hal ini dikarenakan perusahaan yang mempunyai struktur asset yang baik akan lebih mudah mendapatkan kepercayaan dari para investor untuk mendapatkan pinjaman jangka panjang, karena struktur asset bisa menjadi jaminannya. Penelitian ini sejalan dengan hasil penelitian I Wayan Martha Mandana dan Luh Gede Sri Artini (2015).

Pengaruh profitabilitas terhadap struktur modal, dalam penelitian ini menunjukkan bahwa hasil t hitung sebesar $-4,272$ dan nilai signifikan 0,000 , hal ini menyatakan bahwa profitabilitas berpengaruh negatif dan signifikan terhadap struktur modal, artinya bahwa perusahaan yang mempunyai tingkat profitabilitas yang tinggi akan mengurangi ketergantungan modal dari pihak luar, karena tingkat keuntungan yang tinggi memungkinkan perusahaan memperoleh sebagian besar pendanaannya yang dihasilkan secara internal yang berupa laba ditahan sebelum perusahaan menggunakan sumber dana eksternal seperti hutang. Hal tersebut dapat disebabkan karena dengan semakin tinggi nya laba yang diperoleh perusahaan akan semakin banyak dana yang akan diperoleh sebagai sumber dana sehingga penggunaan hutang akan semakin sedikit, sehingga berpengaruh terhadap penentuan komposisi struktur modalnya. Hasil ini sejalan dengan hasil penelitian (Angrita Denziana et al,. 2017)

Pengaruh pertumbuhan perusahaan terhadap struktur modal yang dimoderasi oleh profitabilitas, dalam penelitian ini menunjukkan bahwa t hitung-0,877 dan nilai signifikan 0,384 artinya bahwa profitabilitas tidak dapat memoderasi pengaruh pertumbuhan perusahaan terhadap struktur modal.Hal ini karena dengan adanya penambahan profitabilitas atau kemampuan perusahaan dalam memperoleh laba tidak mempengaruhi pertumbuhan perusahaan terhadap struktur modal. Hal ini sejalan dengan hasil penelitian (Neni Pitriyani et al,.2018)

Pengaruh likuiditas terhadap struktur modal yang dimoderasi oleh profitabilitas, dalam penelitian ini menunjukkan bahwa t hitung $-3,758$ dan nilai signifikan 0,000 yang artinya bahwa profitabilitas mampu memoderasi pengaruh likuiditas terhadap struktur modal. Menurut 
Tunggal (2005) jika perusahaan memutuskan menetapkan modal kerja dalam jumlah yang besar, kemungkinan tingkat likuiditas akan terjaga namun kesempatan memperoleh laba yang besar akan menurun yang pada akhirnya berdampak pada menurunnya profitabilitas. Sebaliknya jika perusahaan ingin memaksimalkan profitabilitas, kemungkinan dapat mempengaruhi tingkat likuiditas perusahaan.Makin tinggi likuiditas, maka makin baiklah posisi perusahaan di mata kreditur. Hal ini sejalan dengan penelitian Diana Dwi Astuti dan Chusnul Hotima (2016).

Pengaruh resiko bisnis terhadap struktur modal dengan profitabilitas sebagai variabel moderasi, dalam penelitian ini menunjukkan bahwa t hitung -1,916 dan nilai signifikan 0,061. Yang artinya bahwa profitabilitas tidak mampu memoderasi pengaruh resiko bisnis terhadap struktur modal, artinya dampak langsung resiko bisnis terhadap struktur modal lebih besar daripada dampak tidak langsung resiko bisnis terhadap strukur modal melalui profitabilitas, dengan hal ini hendaknya perusahaan tetap memperhatikan faktor resiko bisnis dalam pengambilan keputusan pendanaannya. Hal ini sejalan dengan penelitian Danik karyawati et al,.(2017)

Pengaruh struktur asset terhadap strutur modal dengan profitabilitas sebagai variabel moderasi, dalam penelitian ini menunjukkan bahwa t hitung 1,186 dan nilai sig 0,241, artinya adalah profitabilitas tidak mampu memoderasi pengaruh struktur asset terhadap struktur modal, hasil ini menunjukkan meskipun perusahaan memiliki jaminan asset yang memadai untuk mendapatkan utang namun kesempatan tersebut tidak selalu dimanfaatkan . perusahaan hanya akan mengambil hutang apabila dana internal yang digunakan sudah tidak mencukupi untuk biaya operasional. Setiap perusahaan menginginkan laba yang besar. Namun perusahaan dengan tingkat laba yang tinggi tetap memiliki kewajiban membagikan deviden sehingga mereka tetap akan mempertimbangkan secara hati-hati untuk mengambil hutang. Jadi dengan profit yang tinggi tidak dapat menjamin perusahaan untuk menggunakan dana internal saja. Hal ini sejalan dengan penelitian (Ceacillia Srimindarti et al,.2017).

\section{KESIMPULAN}

Penelitian ini bertujuan untuk mengetahui faktor yang berpengaruh terhadap struktur modal dengan profitabilitas sebagai variable moderasi, variabel dalam peenelitian ini terdiri dari variabel dependent (Struktur Modal), independen (Pertumbuhan perusahaan, Likuiditas, Resiko bisnis dan struktur asset) dan variabel moderasi (Profitabilitas).Populasi dalam penelitian ini adalah perusahaan makanan dan minuman yang terdaftar di BEI 2014-2018 dengan metode purposive samplingdiperoleh sampel sebanyak 12 perusahaan.Analisis yang digunakan adalah uji regresi linier berganda. Hasilnya adalah pertumbuhan perusahaan tidak berpengaruh terhadap struktur modal, likuiditas berpengaruh negative dan signifikan terhadap struktur modal, resiko bisnis tidak berpengaruh terhadap struktur modal, struktur asset berpengaruh positif dan signifikan terhadap struktur modal, profitabilitas berpengaruh negatif dan signifikan terhadap struktur modal. Profitabilitas dapat memoderasi pengaruh likuiditas terhadap struktur modal, namun profitabilitas tidak dapat memoderasi variabel pertumbuhan perusahaan, resiko bisnis dan struktur asset.

Keterbatasan dalam penelitian ini adalah Populasi pada penelitian ini terbatas hanya pada perusahaan makanan dan minuman dan hanya menggunakan 5 tahun dan menyebabkan sampel yang digunakan terbatas. Komponen Variabel independen yang digunakan hanya 5 variabel yaitu variabel independent (pertumbuhan perusahaan, Likuiditas, resiko bisnis dan struktur asset ) variabel moderasi (Profitabilitas) sehingga hanya sebesar $51,1 \%$, yang artinya masih banyak variabel yang menjelaskan pengaruh terhadap struktur modal.

Saran bagi penelitian selanjutnya adalah memperluas objek serta sampel penelitian, tidak hanya perusahaan makanan dan minuman saja tetapi bisa ditambah dengan perusahaan sektor industri dan kimia, perusahaan barang konsumsi dan juga menambah tahun penelitiannya. Penelitian selanjutnya sebaiknya menambahkan variabel lain seperti Good Corporate Governance, manajemen laba, CSR, ukuran perusahaan, nilai perusahaan, kepemilikan manajerial, serta mengganti variabel moderating dengan variabel yang dapat 
memperkuat pengaruh variabel independent terhadap variabel dependen seperti nilai perusahaan, ROCE, harga saham dan non debt tax shield.

\section{DAFTAR PUSTAKA}

Amalia, F. N. (2016). Analisis Faktor- faktor yang mempengaruhi Struktur Modal Perusahaan LQ 45 yang terdaftar di Bursa Efek Indonesia. Yogyakarta : Universitas Negeri Yogyakarrta.

Anggelita Pricilia Tijow, H. S. (2018). Pengaruh Struktur Aktiva dan Profitabilitas terhadap Struktur Modal pada Persahaan SektorIndustri Barang Konsumsi Yang terdaftar di Bursa Efek Indonesia. Jurnal Akuntansi, 12.

Bagus, I. (2014). Pengaruh Efektivitas Penerapan SIA, Pemanfaatan dan Kesesuaian Tugas pada Kinerja Karyawan. E- Journal Akuntansi. Universitas Udayana.

Batu Bara, R. A. (2017). Pengaruh Struktur Aktiva, Ukuran perusahaan dan Profitabilitas terhadap Struktur modal. Jurnal Adminstrasi Bisnis Vol.50. No.4, 13.

Brealey, M. R. (2008). Dasar - dasar Manajemen Keuangan Perusahaan Edisi 5 jilid 2 ( Alih Bahasa : Bab Sabran). Jakarta: Erlangga.

Brigham, E. \&. (2014). Dasar- Dasar Manajemen Keuangan. Jakarta: Salemba Empat.

Brigham, E. F. (2011). Dasar - Dasar Manajemen Keuangan Buku 1-11/E. Jakarta: Salemba Empat.

Brigham. E, .. \&. (2013). Dasar-Dasar Manajemen Keuangan. Jakarta: Salemba Empat.

Chandrarin, G. (2018). Metode Riset Akuntansi Pendekatan Kuantitatif. Jakarta: Salemba Empat.

Danik Karyawati, Y. D. (2017). Analisis Resiko Bisnis Dan Ukuran Perusahaan Terhadap Struktur Modal dengan Profitabilitas sebagai Variabel Intervening. Jurnal Akuntasi Keuangan.

Denziana, A. \&. (2017). Pengaruh Profitabilitas, Struktur Aktiva dan Ukuran Perusahaan Terhadap Nilai perusahaan terhadap Struktur Modal Pada Perusahaan Real Estate And Property Yang terdaftar di Bursa Efek Indonesia Tahun 2015.Jurnal Akuntansi \& Keuangan, 51-67.

Dewi, D. M. (2016). Pengaruh Likuiditas, Leverage, Ukuran Perusahaan Terhadap Kebijakan Dividen Tunai dengan profitabilitas sebagai variabel intervening. BJurnal Bisnis dan Ekonomi, 12-19.

DewiNingrat, A. I. (2018). Pengaruh likuiditas, Profitabilitas dan Struktur Asset terhadap Struktur Modal. Jurnal IImiah Manajemen, 14.

Gede, I. W. (2015). Faktor-faktor yang Mmempengaruhi Struktur Modal Pada PT. PLN Distribusi Bali. E- Jurnal Manajemen.

Gitman, L. J. (2003). Principles Of Manajerial Finance 10 Edition. Boston: International Edition.

Hardiningsih, C. S. (2017). Pengaruh Struktur Asset perusahaan terhadap Struktur Modal di Moderasi dengan Profitabilitas. Jurnal IImiah Manajemen, 348-360.

Horne, V. J. (2007). Fundamentals of Financial management, prinsip-prinsip Manajemen Keuangan. Jakarta: Salemba Empat.

Hotima, D. D. (2016). Variabel yang Berpengaruh terhadap Struktur Modal dengan Profitabilitas sebagai Variabel Intervening.Jurnal Akkuntansi Keuangan. 
Housten, B. \&. (2011). Dasar- Dasar Manajemen Keuangan Edisi sepuluh. Jakarta: Salemba Empat.

Kusmuriyanto. (2005). Akuntansi Keuangan Dasar. Semarang: UPT. UNNES Press.

Kustyaningrum, D., Nuraina, E., \& Wijaya, L. (2016). Pengaruh Leverage, Likuiditas, Profitabilitas, Dan Umur Obligasi Terhadap Peringkat Obligasi (Studi Pada Perusahaan Terbuka Yang Terdaftar Di Bursa Efek Indonesia). Jurnal Akuntansi dan Pendidikan, 5(1), 25-40.

Mahardika, S. O. (2017). Pengaruh Struktur Aktiva, Resiko Bisnis, dan Ukuran perusahaan Terhadap Struktur Modal dengan Profitabilitas sebagai variabel Moderating. Jurnal Ekonomi Akuntansi.

Myers, B. d. (2018). Dasar- Dasar Manajemen Keuangan Perusahaan ( Alih Bahasa: Bob Sabran MM). Buku Edisi ke-5. Jakarta: Erlangga.

Neni Pitriyani, W. I. (2018). Pengaruh Pertumbuhan Perusahaan Terhadap Struktur Modal Dengan Profitabilitas Sebagai variabel Intervening.Jurnal Ekonomi.

Neni Pitriyani, W. I. (Vol. 13, No 2 Oktober 2018). Pengaruh Pertumbuhan perusahaan terhadap Struktur Modal Dengan Profitabilitas sebagai Variabel Intervening. Jurnal Ekonomi.

Oscarina, S. (2017). Pengaruh Struktur Aktiva, Resiko Bisnis dan Ukuran perusahaan terhadap Struktur Modal. Jurnal Akuntansi keuangan UNNES.

Priyatno. (2014).Riski Ayu Pratiwi Batubara, T. Z. (2017). Pengaruh Struktur Aktiva, Ukuran Perusahaan, dan Profitabilitas Terhadap Struktur Modal (Studi pada perusahaan Makanan dan Minuman Yang terdaftar di BEI Tahun 2012-2015. Administrasi Bisnis.

Sabir, M. d. (2012). Determinants Of Capital Structure A Study of oil and gas Sector Of Pakistan. Accounting.

Saidi. (2004). Laporan Keuangan. Edisi Keempat. Yogyakarta: Liberty.

Saidi, C. (2004). Faktor- Faktor yang Mempengaruhi Struktur Modal pada Perusahaan Manufaktur Go Public Di BEJ Tahun 1997-2002. Jurnal Bisnis dan Ekonomi, Vol 11, No.1 Maret, Hal 44-58.

Sartono, R. (2001). Manajemen Keuangan Edisi 3. Yogyakarta: BPFE UGM.

Sugiyono. (2003). Metode penelitian. Bandung: Alfabeta.

Sugiyono. (2009). Metode penelitian pendidikan (Pendekatan Kuantitatif Kualitatif dan R\&D). Bandung: Penerbit CV Alfabeta.

Susantika, B. (2019). Pengaruh Ukuran Perusahaan, Likuiditas dan Struktur Aktiva terhadap Struktur Modal dengan Profitabilitas sebagai variabel Intervening.Jurnal Akuntansi Keuangan UNDIP.

Susantika, B. (2019). Pengaruh Ukuran Perusahaan, Likuiditas dan Struktur Aktiva terhadap Struktur Modal dengan Profitabilitas sebagai Variabel Interveningnya (Studi pada perusahaan Manufaktur Sektor Aneka Industri yang Terdaftar di Bursa Efek Indonesia Tahun 2012-2016). Ekonomi dan Bisnis.

Sutrisno. (2012). Dalam Manajemen Keuangan dan Teori, Konsep dan Aplikasi. Yogyakarta: Ekonisia.

Titman, S. d. (1988). The Determinants Of Capital Structur Choice,. The Journal Of Finance. Vol 43. March No.1. 
Umam, M. C. (2014). Pengaruh Ukuran Perusahaan dan Likuiditas Terhadap Struktur Modal dengan Profitabilitas Sebagai Variabel Interveningnya.Ekonomi dan Bisnis.

Weston, F. J. (2013). Manajemen keuangan Jilid 2. Jakarta: Binarupa Aksara Publisher.

Wijayanti, H. H. (2017). Analisis Pengaruh Karakteristik Perusahaan Terhadap Struktur Modal Melalui Profitabilitas (Studi Kasus pada Bank Umum Syariah di Indonesia Tahun 20112016). Salatiga: Jurnal IAIN Salatiga. 